\title{
BIOLOGICALLY SYNTHESISED COPPER OXIDE AND ZINC OXIDE NANOPARTICLE FORMULATION AS AN ENVIRONMENTALLY FRIENDLY WOOD PROTECTANT FOR THE MANAGEMENT OF WOOD BORER, Lyctus africanus
}

\author{
K. S. Shiny ${ }^{1, \star}$ \\ https://orcid.org/0000-0002-5543-4274 \\ R. Sundararaj ${ }^{1}$ \\ https://orcid.org/0000-0001-8858-9312
}

\begin{abstract}
The management of Lyctus africanus, one of the major dry wood pests in the tropical region is difficult due to its secluded habits and long lifecycle and therefore, its control measures are limited to the usage of insecticides. The insecticides particularly the metal salts are effective, but in some cases their leaching leads to concerns about environmental pollution. Nanometal particles are found to be more effective than metal salts. Presently available metal nanoparticles are synthesized using physical or chemical methods and their production results in toxic by-products and are costly. The current investigation deals with synthesis and use of metal nanoparticle for wood protection in an environmentally friendly and cost-effective way. The plant extracts that are reported to have wood preservative properties were used for the synthesis of metal nanoparticles. Copper oxide and zinc oxide nanoparticles were synthesized using leaf extracts of Lantana camara. The efficacy of the synthesized Lantana camara leaf extract and copper oxide or zinc oxide nanoparticle formulation as a wood protectant was tested against Lyctus africanus according to standard BIS. The formulation of copper oxide nanoparticle and Lantana camara leaf extract effectively protected the treated rubberwood blocks from Lyctus africanus attack, when compared to zinc oxide nanoparticle Lantana camara leaf extract formulation and can be developed into a stable, ecofriendly wood preservative.
\end{abstract}

Keywords: Biological synthesis, Lantana camara, Lyctus africanus, nanoparticles, wood protection.

\section{INTRODUCTION}

The powder post beetle Lyctus africanus, a destructive wood borer of timber and its products is one of the most serious pests of economic importance (Helal 1983, Creffield 1996). Timber characteristics such as moisture, starch content and vessel size suitable for the insertion of the ovipositor of the lyctid beetles are the factors that determines the susceptibility of the timber to the pests (Peters et al. 2002, Ito 1983). Kartika and Yoshimura (2013) confirmed the importance of starch and sugar to attract adult females of L. africanus to lay their eggs on starchy sites. In general, it is difficult to detect the initial stages of infestation of this beetle and is unnoticed until attack is much advanced. The main sign of an active infestation of L. africanus is small accumulations of fine powder below exit holes in infested wood (Peters et al. 2002). The efforts to study and control them is complicated due to their reclusive habits and relatively long generation time (Tan et al. 2003).

Wood preservative treatment is an effective control measure and it protects wood and wood products from deteriorating organisms like decay fungi and wood boring insects (Lebow 2010). It involves use of toxic or repellent wood preservatives and chemical pesticides for increasing the durability and decay resistance of wood 
(Lepage et al. 2017). Many chemicals and pesticides have been recommended as preservatives for the protection of non-durable timbers against borers (Gnanaharan and Mathew 1982, Gnanaharan et al. 1983, Ali and Hashim 2019) which includes commercial chlorpyriphos formulations (Remadevi and Muthukrishnan 1997), diffusion formulation of Boracol-40 (Creffield et al. 1983), lindane or cypermethrin (Van Acker et al.1990), chlorpyriphos in solution (Fears and Leca 1995, Tolley et al. 1998) and copper ethanolamine (Kalawate 2013). The conventional wood preservatives are very effective to protect wood but their usage often lead to environmental pollution. The leaching of these toxic constituents from the treated wood in use is a matter of concern as these are hazardous to animals and human beings even after disposal (Venmalar 2017, Lepage et al. 2017). Groenier and Lebow (2006) reported that there are efforts to restrict, replace or eliminate the use of wood preservatives currently in use and, researchers are in search of developing new wood preservatives which are environmentally friendly, efficient, less toxic and cost effective.

Metals especially salts of copper, zinc and boron are reported to be effective as wood preservatives alone or in combination with other compounds (Richardson 1997, Zabel and Morrel 1992, Ash and Ash 2004). The disadvantage of using metal salts is their leachability (Lebow 1996, Temiz et al. 2014). Humar et al. (2001) has discussed the leaching of copper from treated wood and suggested amines as a fixative, a substitute for toxic chromium. Freeman and McIntyre (2008) and Kartal et al. (2009) reported that metal nanoparticles are less leachable compared to metal salts and can provide much higher retention resulting in higher biological durability of wood. Many researchers have reported the use of nanometals for protecting wood (Clausen 2007, Kartal et al. 2009, Clausen et al. 2010, Akhtari and Arefkhani 2010, Bak et al. 2012, Terzi et al. 2016, Lykidis et al. 2016, Nair et al. 2017). Borges et al. (2018) has reviewed the advances and application of nanotechnology in wood protection.

But there are concerns about the impacts of nanoparticles on various systems and environment which requires proper understanding and investigation. Platten et al. (2014) reported the potential of the release of copper nanoparticles from pressure treated lumber. Civardi et al. (2015) reported the possible environmental fate of Cu-based nanoparticles from wood preservatives. Reports are available in literature showing the negative impacts of nanoparticles on plant system, soil microbial community, and rhizosphere (Raffi and Husen 2019, Wagay et al. 2019, Husen and Iqbal 2019). Accumulation of nanoparticles cause human health problems (Siddiqui et al. 2013, Dwivedi et al. 2018). There are reports of nanoparticles used for plant growth improvement, increased seed germination, nutrient quality, pest management, food additives, packaging materials and as health supplements also (Khot et al. 2012, Sekhon 2014, Oliveira et al. 2015, Kumar et al. 2017, Duhan et al. 2017, Cao et al. 2018, Husen and Iqbal 2019). Therefore, issues related to optimal use of nanoparticle and its ethical and social implications in different systems needs appropriate consideration.

Nanometals which are reported to protect wood are synthesized by employing physical or chemical methods and these procedures are energy intensive with the use of toxic chemicals and are expensive (Vijayaraghavan and Ashokkumar 2017). Singh et al. (2018) has summarized the current state of research on the green synthesis of metal and metal oxide nanoparticles with their advantages over chemical synthesis methods. Biological synthesis of nanoparticle is possible by using biomaterials such as fungi (Dhillon et al. 2012), virus (Dujardin et al. 2003), bacteria (Hulkoti and Taranathm 2014), microalgae (Schrofel et al. 2011), yeast (Moghaddam et al. 2015), plant extracts (Mittal et al. 2013) and macroalgae (Singaravelu et al. 2007) as an alternate, ecofriendly, non-toxic method of synthesis. Among the biomaterials, plants are preferred over other biomaterials, because of their availability, renewability, simplicity of process, efficiency, cost effectiveness and most importantly, stability of the synthesized nanoparticles (Vijayaraghavan and Ashokkumar 2017, Iravani 2011). Singh et al. (2018) has reviewed research on green synthesis of metal and metal oxide nanoparticles, their use in environmental remediation and their environmental impact or toxicity. Shiny et al. (2019) reported a preliminary study on copper oxide nanoparticle biosynthesis using selected leaf extracts and its effectiveness as wood preservative against decay fungi and termites. Current research work is the first study to examine the efficacy of biologically synthesized copper oxide $(\mathrm{CuO})$ and zinc oxide $(\mathrm{ZnO})$ nanoparticle formulation using Lantana camara leaf extract against the wood borer Lyctus africanus.

\section{MATERIALS AND METHODS}

\section{Chemicals}

Copper sulphate $\left(\mathrm{CuSO}_{4}, 5 \mathrm{H}_{2} \mathrm{O}\right)$, Zinc nitrate $\left(\mathrm{Zn}\left(\mathrm{NO}_{3}\right)_{2}, 6 \mathrm{H}_{2} \mathrm{O}\right)$, Copper oxide $(\mathrm{CuO})$, and Zinc oxide $(\mathrm{ZnO})$ were procured from Hi-Media Laboratories, Mumbai, India. Copper oxide $(\mathrm{CuO})$ nanopowder $(<50$ 
$\mathrm{nm})$ and zinc oxide $(\mathrm{ZnO})$ nanopowder $(<100 \mathrm{~nm})$ were procured from Sigma Aldrich Chemicals Pvt. Ltd., Bengaluru, India.

\section{Maintenance of laboratory cultures of Lyctus africanus}

Culture of Lyctus africanus (Lesne) was maintained on dried tapioca chips in the laboratory as suggested by Nair and Mathew (1984). Thin slices of raw tapioca were dried in an oven at $60{ }^{\circ} \mathrm{C}$ in the laboratory or in sunlight. Adults of $L$. africanus collected from the field were confirmed using light microscope and released into glass bottles containing dry tapioca chips. The glass bottles were covered either by lids fitted with fine mesh or by muslin cloths and kept in a dry place in the laboratory. After two months, the establishment of culture was verified by taking out the tapioca slices from the culture and examining the stages under light microscope. Adults emerged from the culture were used for the study.

\section{Preparation of test specimens}

Rubberwood, Hevea brasiliensis (Willd. ExAdr. Juss.) Muell. Arg., which is classified as perishable wood (Findlay 1985) was procured from M/s Starline Packers Pvt. Ltd, Bengaluru, India. Wood specimens of rubberwood with the specification of $50 \times 25 \times 15 \mathrm{~mm}^{3}$, free from knots, mould, stain, and any visual defects, with long axis parallel to the grain of the wood were prepared according to IS 4873 Part 2 (2008) with some modification. These wood specimens were tested for the presence of adequate starch content as described by Kartika and Yoshimura (2013). Rubberwood specimens containing abundant starch grains were selected and six matched replicates were used for the treatment and six matched untreated rubberwood specimens served as control. The required rubberwood specimens were numbered, dried and stored in desiccators prior to treatment.

\section{Synthesis of copper oxide and zinc oxide nanoparticles by using Lantana camara leaf extract}

Fresh leaves of Lantana camara (Lantana) were collected from Nallal, Karnataka and were used for the synthesis of $\mathrm{CuO}$ and $\mathrm{ZnO}$ nanoparticles. Leaf extract $20 \%$ by weight was prepared as per the procedure adopted by Shiny et al. (2019). Precursor solution of $\mathrm{CuSO}_{4}, 5 \mathrm{H}_{2} \mathrm{O}$ and $\mathrm{Zn}\left(\mathrm{NO}_{3}\right)_{2}, 6 \mathrm{H}_{2} \mathrm{O}$ were prepared $(0,025 \mathrm{M})$ and preheated separately in a water bath at $60^{\circ} \mathrm{C}$ for 30 minutes. The leaf extract was also preheated in a water bath at $60^{\circ} \mathrm{C}$ for 30 minutes and was mixed with respective precursor solutions at 1:4 proportions (Majumder 2012). The resultant formulations were kept in a water bath at $80{ }^{\circ} \mathrm{C}$ for 10 minutes, stirred at $104,71 \mathrm{rad} / \mathrm{sec}$ for 10 minutes and kept at room temperature for $1 \mathrm{~h}$. The formulations containing copper oxide or zinc oxide nanoparticles and Lantana leaf extract were used for the testing. The formulation was composed of Lantana leaf extract at $20 \% \mathrm{w} / \mathrm{v}$ having an estimated concentration of $0,499 \% \mathrm{CuSO}_{4}$ with an active ingredient of copper at $0,13 \%$. Similarly, $\mathrm{ZnO}$ nanoparticle Lantana leaf extract formulation was composed of $20 \%$ $\mathrm{w} / \mathrm{v}$ of Lantana leaf extract with an estimated concentration of $0,594 \%$ of $\mathrm{Zn}\left(\mathrm{NO}_{3}\right)_{2}$ with an active ingredient of zinc at $0,2 \%$.

Reference solutions for the test viz. Copper sulphate $\left(\mathrm{CuSO} 4,5 \mathrm{H}_{2} \mathrm{O}\right)$, Zinc nitrate $\left(\mathrm{Zn}\left(\mathrm{NO}_{3}\right)_{2}, 6 \mathrm{H}_{2} \mathrm{O}\right)$, Copper oxide nanopowder, Zinc oxide nanopowder, Copper Oxide $(\mathrm{CuO})$ and $\mathrm{Zinc}$ oxide $(\mathrm{ZnO})$ solutions were prepared at a concentration of $0,5 \%$ using distilled water.

\section{Characterization of biologically synthesized $\mathrm{CuO}$ and $\mathrm{ZnO}$ nanoparticles}

Scanning electron microscopy (SEM) coupled with Energy dispersive analysis X-ray (EDAX) was used for the characterization of the synthesised $\mathrm{CuO}$ and $\mathrm{ZnO}$ nanoparticles as per the method described by Shiny et al. (2019).

\section{Pressure impregnation method and retention}

Rubberwood specimens were pressure impregnated with $\mathrm{CuO}$ and $\mathrm{ZnO}$ nanoparticle Lantana formulations, Lantana leaf extract and reference solutions respectively. Rubberwood specimens were completely immersed in the treatment solution kept in the pressure impregnation chamber, a vacuum of 3,99 kPa was applied for $15 \mathrm{~min}$ followed by a pressure $344,74 \mathrm{kPa}$ for $60 \mathrm{~min}$. After the treatment rubberwood specimens were taken out of the treatment solution, drained completely, weighed and then air dried to constant weight. Average preservative retention for rubberwood specimens treated with the solution was calculated.

Retention was calculated as per ASTM D1413-05 (2005) using the following Equation 1. 


$$
\text { Retention }\left(\mathrm{kg} / \mathrm{m}^{3}\right)=\frac{G \times C}{100 \times V}
$$

$\mathrm{G}=\left(\mathrm{W}_{2}-\mathrm{W}_{1}\right) \mathrm{g}$ i.e., $\mathrm{kg}$ of preservative absorbed by the block

$\mathrm{C}=$ concentration of preservative $(\%)$

$\mathrm{V}=$ volume of the specimens $\left(\mathrm{m}^{3}\right)$

Mean retention of six samples per treatment was calculated.

\section{Laboratory testing of the preservative formulation against borer Lyctus africanus}

The performance of a newly developed preservative formulation is bioassayed as per IS 4873 Part 2 (2008). In this method, the rubberwood test specimens were stored individually in glass containers provided with finely woven cotton cover to prevent mite infestation. The temperature and relative humidity during the test were maintained at $25^{\circ} \mathrm{C}$ to $30{ }^{\circ} \mathrm{C}$ and 70 to $75 \%$ respectively. The treated rubberwood specimens were exposed to four pairs of adult L. africanus. Presence of exit holes is an indication of the number of emerged beetles and is a measure of the effectiveness of the treatment. The control and treated rubber wood specimens were examined periodically for the presence of exit (emergence) holes. The number of exit holes in each test specimen was counted manually and the time taken for the appearance of first exit hole was recorded. The number of exit holes or the number of emerged beetles from treated wood and control wood exposed to $L$. africanus were compared. Mean and standard deviation were calculated using Microsoft Excel Package.

\section{RESULTS AND DISCUSSION}

Formulations containing copper oxide and zinc oxide nanoparticles were prepared using Lantana leaf extract. The presence of $\mathrm{CuO}$ nanoparticle was indicated by the change in colour from bluish green to dark green and finally to brown and $\mathrm{ZnO}$ nanoparticle, by the turbidity of the solution. This is in agreement with earlier reported studies of Majumder (2012), Gopinath et al. (2014), Mandava et al. (2017), Fakhari et al. (2019) and Ezealisiji et al. (2019).

\section{Characterization of biologically synthesized $\mathrm{CuO}$ and $\mathrm{ZnO}$ nanoparticles}

Scanning electron micrograph (SEM) of $\mathrm{CuO}$ and $\mathrm{ZnO}$ nanoparticles synthesised using Lantana leaf extract is shown in Figure 1. The synthesised nanoparticles were not agglomerated. The synthesized $\mathrm{CuO}$ nanoparticles were found to be spherical in shape with a particle size of $33 \mathrm{~nm}$ to $46 \mathrm{~nm}$. Particle size of the synthesized $\mathrm{ZnO}$ nanoparticle was between $34 \mathrm{~nm}$ and $37 \mathrm{~nm}$. EDAX profile confirmed the presence of copper and zinc in major fraction (Figure 1). This is in agreement with earlier reports by Lee et al. (2011), Khan et al. (2017), Punjabi et al. (2015). 

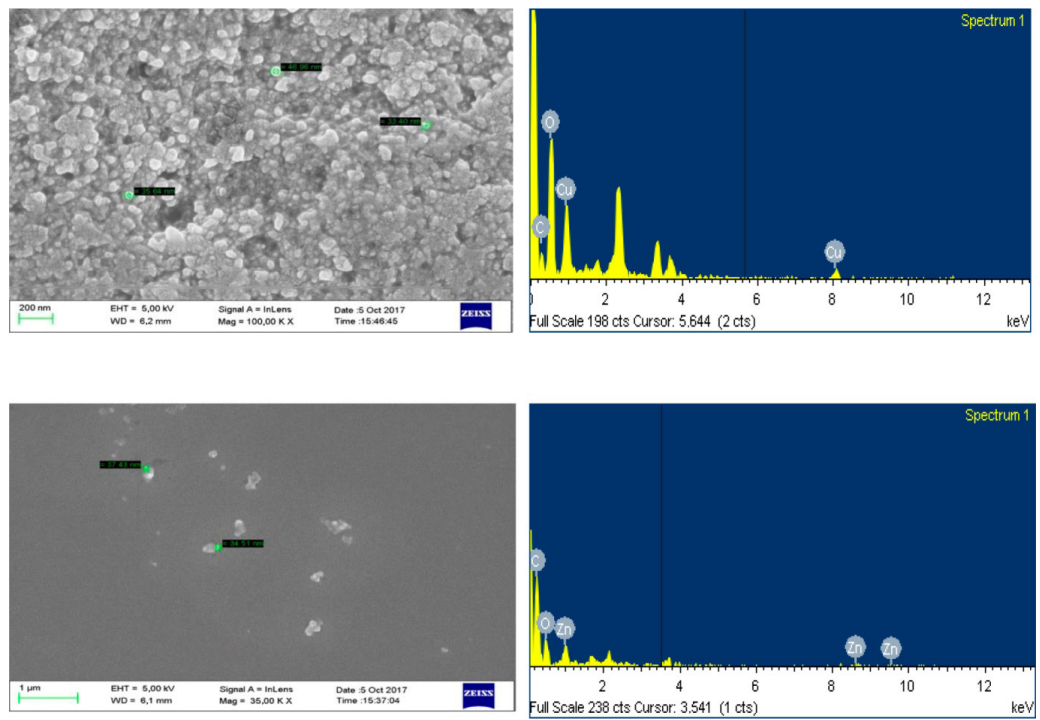

Figure 1: Biologically synthesized (a) $\mathrm{CuO}$ and (b) $\mathrm{ZnO}$ nanoparticles using L. camara extracts (Shiny et al. 2019).

\section{Retention of the preservative formulation}

Retention is expressed as kilograms of preservative per cubic meter of wood (Canadian wood council 2018) and is a measure of the amount of preservative that is retained in the wood after the treatment. It is one way of expressing the effectiveness of the preservative used and the treatment method employed. Table 1 shows the retentions of preservative formulations in rubberwood. It was observed that rubberwood test specimens retained similar amount for all the three preservative formulations. The uptake of reference solutions at a concentration of $0,5 \%$ was also found to be similar.

Table 1: Retention of preservative solution in treated rubberwood.

\begin{tabular}{|c|c|}
\hline Sample & Retention of solution $\left(\mathrm{kg} \cdot \mathrm{m}^{-3}\right)$ \\
\hline Lantana camara leaf extract & $312,51 \pm 12,79$ \\
\hline $\mathrm{CuO}-\mathrm{Np}$-Lantana camara leaf extract formulation & $322,15 \pm 7,93$ \\
\hline $\mathrm{ZnO}-\mathrm{Np}$ - Lantana camara leaf extract formulation & $307,96 \pm 6,80$ \\
\hline $\mathrm{CuSO}_{4}, 5 \mathrm{H}_{2} \mathrm{O}(0,5 \%)$ & $277,72 \pm 18,28$ \\
\hline $\mathrm{Zn}\left(\mathrm{NO}_{3}\right)_{2}, 6 \mathrm{H}_{2} \mathrm{O}(0,5 \%)$ & $274,98 \pm 9,78$ \\
\hline $\mathrm{CuO} \mathrm{Np}(0,5 \%)$ & $271,46 \pm 6,24$ \\
\hline $\mathrm{ZnO} \mathrm{Np}(0,5 \%)$ & $278,63 \pm 5,97$ \\
\hline $\mathrm{CuO}(0,5 \%)$ & $275,14 \pm 9,07$ \\
\hline $\mathrm{ZnO}(0,5 \%)$ & $279,76 \pm 20,86$ \\
\hline
\end{tabular}

Mean of six replicates.

\section{Laboratory testing of the preservative formulation against borer $L$. africanus}

Untreated control specimens of rubberwood developed exit holes within six months of inoculation of the $L$. africanus. The number of exit holes in the control specimens has increased progressively thereafter. Similarly, rubberwood specimens treated with Lantana leaf extract alone has also developed exit holes within six months (Table 2). This clearly indicates that Lantana leaf extract alone does not impart any protection to treated wood specimens against borers. After two years of inoculation, all the rubberwood specimens treated with $\mathrm{CuO}$ nanoparticle Lantana leaf extract formulation and tested were free of $L$. africanus attack evidenced by the absence of exit holes (Figure 2). Whereas, rubberwood specimens treated with $\mathrm{ZnO}$ nanoparticle Lantana leaf extract formulation developed exit holes after six months of exposure to $L$. africanus. The numbers of emergence holes in the control and Lantana leaf extract treated rubberwood blocks were 35,33 $\pm 2,5$ and 45,66 $\pm 4,0$ respectively. Whereas, the number of exit holes in the $\mathrm{ZnO}$ nanoparticle Lantana leaf extract formulation treated rubberwood blocks was 25,66 \pm 9,5 (Table 3). 
It was observed that, after 2 years, wood specimens treated with reference solutions of Copper sulphate $\left(\mathrm{CuSO} 4,5 \mathrm{H}_{2} \mathrm{O}\right)$, Zinc nitrate $\left(\mathrm{Zn}\left(\mathrm{NO}_{3}\right)_{2}, 6 \mathrm{H}_{2} \mathrm{O}\right)$, Copper oxide nanopowder, Zinc oxide nanopowder, Copper Oxide $(\mathrm{CuO})$ and $\mathrm{Zinc}$ oxide $(\mathrm{ZnO})$ solutions at a concentration of $0,5 \%$ also developed exit holes (Figure 3 ).

The results indicate that $\mathrm{CuO}$ nanoparticle Lantana leaf extract formulation gave better protection to the treated rubberwood specimens for a period of two years compared to $\mathrm{ZnO}$ nanoparticle Lantana leaf extract formulation against $L$. africanus. Reference solutions of Copper sulphate $\left(\mathrm{CuSO}_{4}, 5 \mathrm{H}_{2} \mathrm{O}\right)$, Zinc nitrate $(\mathrm{Zn}$ $\left(\mathrm{NO}_{3}\right)_{2}, 6 \mathrm{H}_{2} \mathrm{O}$, Copper oxide nanopowder, Zinc oxide nanopowder, Copper Oxide $(\mathrm{CuO})$ and $\mathrm{Zinc}$ oxide $(\mathrm{ZnO})$ solutions failed to protect the treated wood specimens against $L$. africanus beetles. Whereas, the low resistance offered by reference solutions can be attributed to the lower concentration and to the choice of the medium used to prepare the test solution (Nair et al. 2017, Nair et al. 2018, Terzi et al. 2016). It can be concluded that, since both Lantana leaf extract and reference solutions alone does not offer any kind of protection to the treated rubberwood specimens, the protection offered by $\mathrm{CuO}$ nanoparticle Lantana leaf extract formulation against L. africanus is due to synergistic effect of the synthesised $\mathrm{CuO}$ nanoparticles and Lantana leaf extract in the formulation.

Reports by Kartal et al. (2009), Mantanis et al. (2014) and Nair et al. (2017) have already indicated that $\mathrm{CuO}$ nanoparticles are capable of protecting wood from insects and fungi. Many plant extracts have reported to possess both antifungal effect and wood preservative properties (Tascioglu et al. 2013). Zandi-Sohani et al. (2012) has evaluated L. camara essential oil against infesting beetles Callosobruchus maculates (Fabricius) and reported to be effective. Gupta et al. (2017a), Gupta et al. (2017b) reported wood protection properties of $L$. camara in terms of its effect on dimensional stability of wood and inhibitory effect on wood decay fungi. Since both $\mathrm{CuO}$ nanoparticles and Lantana leaf extracts have demonstrated wood protective effects, the synergistic effect of both might have contributed to the significant level of protection offered to treated rubberwood specimens against L. africanus. Lee et al. (2011) and Khan et al. (2017) have reported that, plant extract components can act as both stabilizing and reducing agents maintaining the properties of the synthesized $\mathrm{CuO}$ nanoparticles.

Table 2: Appearance of exit holes as per IS (4873 Part 2 2008).

\begin{tabular}{|c|c|c|c|c|c|c|}
\hline $\begin{array}{l}\text { No. of months after } \\
\text { inoculation } \rightarrow \\
\text { Treatment } \downarrow\end{array}$ & 3 & 6 & 9 & 12 & 18 & 24 \\
\hline Control & $\mathrm{NEH}$ & EHA & MEHA & MEHA & MEHA & MEHA \\
\hline Lantana camara leaf extract & NEH & EHA & EHA & MEHA & MEHA & MEHA \\
\hline $\begin{array}{l}\text { CuO-Np-Lantana camara leaf } \\
\text { extract formulation }\end{array}$ & $\mathrm{NEH}$ & NEH & $\mathrm{NEH}$ & $\mathrm{NEH}$ & NEH & $\mathrm{NEH}$ \\
\hline $\begin{array}{l}\mathrm{ZnO}-\mathrm{Np} \text { - Lantana camara leaf } \\
\text { extract formulation }\end{array}$ & NEH & NEH & EHA & EHA & MEHA & MEHA \\
\hline $\mathrm{CuSO}_{4}, 5 \mathrm{H}_{2} \mathrm{O}(0,5 \%)$ & $\mathrm{NEH}$ & $\mathrm{NEH}$ & $\mathrm{NEH}$ & $\mathrm{NEH}$ & EHA & EHA \\
\hline $\mathrm{Zn}\left(\mathrm{NO}_{3}\right)_{2}, 6 \mathrm{H}_{2} \mathrm{O}(0,5 \%)$ & $\mathrm{NEH}$ & NEH & $\mathrm{NEH}$ & EHA & EHA & EHA \\
\hline $\mathrm{CuO} \mathrm{Np}(0,5 \%)$ & $\mathrm{NEH}$ & EHA & EHA & EHA & MEHA & MEHA \\
\hline $\mathrm{ZnO} \mathrm{Np}(0,5 \%)$ & $\mathrm{NEH}$ & EHA & EHA & EHA & MEHA & MEHA \\
\hline $\mathrm{CuO}((0,5 \%)$ & $\mathrm{NEH}$ & EHA & EHA & EHA & MEHA & MEHA \\
\hline $\mathrm{ZnO}(0,5 \%)$ & $\mathrm{NEH}$ & EHA & EHA & EHA & MEHA & MEHA \\
\hline
\end{tabular}

NEH -No exit holes; EHA-Exit holes appeared; MEHA-More exit holes appeared.

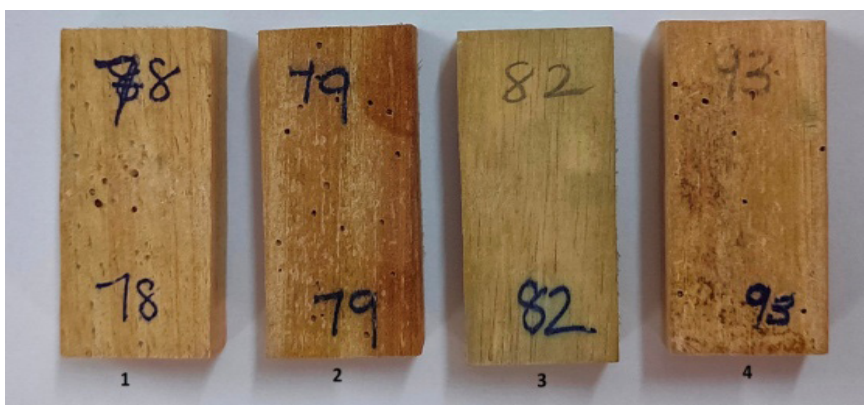

Figure 2: Rubberwood blocks after 2 years of exposure to L. africanus as per IS (4873 Part 2 2008).

1. Control, 2. Treated with L. camara leaf extract, 3. Treated with CuO-Np-L. camara formulation, 4. Treated with $\mathrm{ZnO}-\mathrm{Np}-L$. camara formulation. 


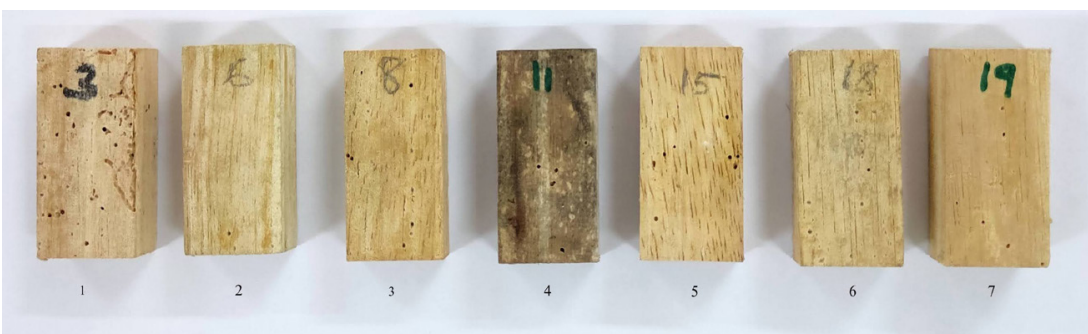

Figure 3: Rubberwood blocks after 2 years of exposure to L. africanus as per IS (4873 Part 2 2008). 1. Control, 2. Treated with $\mathrm{CuSO}_{4}, 5 \mathrm{H}_{2} \mathrm{O}(0,5 \%), 3$. Treated with $\mathrm{Zn}\left(\mathrm{NO}_{3}\right)_{2}, 6 \mathrm{H}_{2} \mathrm{O}(0,5 \%)$, 4. Treated with $\mathrm{CuO} \mathrm{Np}(0,5 \%), 5$. Treated with $\mathrm{ZnO} \mathrm{Np}(0,5 \%), 6$. Treated with $\mathrm{CuO}((0,5 \%)$, 7 . Treated with $\mathrm{ZnO}(0,5$ $\%)$.

Table 3: Laboratory evaluation against L. africanus.

\begin{tabular}{|c|c|c|}
\hline Samples & $\begin{array}{c}\text { Number of exit } \\
\text { (emergence) holes } \\
(\text { Mean } \pm \mathrm{sd})\end{array}$ & $\begin{array}{c}\text { Time taken for } \\
\text { emergence in days } \\
(\text { Mean } \pm \mathrm{sd})\end{array}$ \\
\hline Control & $35,33 \pm 2,5$ & $145,66 \pm 2,0$ \\
\hline Lantana camara leaf extract & $45,66 \pm 4,0$ & $156,0 \pm 3,4$ \\
\hline CuO-Np-L. camara extract formulation & 0 & 0 \\
\hline $\mathrm{ZnO}-\mathrm{Np}-L$. camara extract formulation & $25,66 \pm 9,5$ & $225,66 \pm 5,6$ \\
\hline $\mathrm{CuSO}_{4}, 5 \mathrm{H}_{2} \mathrm{O}(0,5 \%)$ & $8,3 \pm 4,5$ & $461,6 \pm 11,9$ \\
\hline $\mathrm{Zn}\left(\mathrm{NO}_{3}\right)_{2}(0,5 \%)$ & $10,3 \pm 4,0$ & $345,0 \pm 6,2$ \\
\hline $\mathrm{CuO} \mathrm{Np}(0,5 \%)$ & $29,6 \pm 13,5$ & $164,6 \pm 13,3$ \\
\hline $\mathrm{ZnO} \mathrm{Np}(0,5 \%)$ & $25,0 \pm 29,4$ & $146,0 \pm 4,0$ \\
\hline $\mathrm{CuO}(0,5 \%)$ & $13,3 \pm 15,3$ & $171,3 \pm 5,0$ \\
\hline $\mathrm{ZnO}(0,5 \%)$ & $15,0 \pm 7,9$ & $167,3 \pm 3,0$ \\
\hline
\end{tabular}

\section{CONCLUSIONS}

It has been concluded that Lantana camara leaf extract has the potential for the biological synthesis of $\mathrm{CuO}$ and $\mathrm{ZnO}$ nanoparticles. Formulations containing Lantana leaf extract and $\mathrm{CuO}, \mathrm{ZnO}$ nanoparticles were tested against Lyctus africanus which is a serious timber pest. Lantana leaf extract and $\mathrm{CuO}$ nanoparticle formulation was found to be effective against the beetles for a period of two years where as Lantana leaf extract $\mathrm{ZnO}$ nanoparticle formulation was effective for a period of six months only. This can be attributed to the synergistic effect of the properties of Lantana leaf extract and the synthesized nanoparticles as both Lantana leaf extract and reference solutions alone failed to protect the treated rubberwood specimens from L. africanus attack. Since the prophylactic treatment of timber with the Lantana leaf extract and $\mathrm{CuO}$ nanoparticle formulation effectively protected the timber from beetle attack, it can be recommended for the management of $L$. africanus while lessoning potential detrimental effects on the environment. But to assess the possibility of using this formulation as a wood protectant, further investigation regarding leachability and stability of the formulation are required.

\section{ACKNOWLEDGEMENTS}

The authors gratefully acknowledge UGC, India for providing the PDF grant (No. F./PDFSS-2015-17KAR-1161) and The Director, Institute of Wood Science and Technology (IWST) for providing the infrastructure. The assistance of CeNSE, IISc, Bangalore, India for the SEM-EDAX analysis is gratefully accredited. The valuable support offered by Dr. Sreeja Nair in preparing the manuscript is thankfully acknowledged.

\section{REFERENCES}

Akhtari, M.; Arefkhani, M. 2010. Application of Nanotechnology in Wood Preservation. In $41^{\text {st }}$ Annual Meeting of the International Research Group on Wood Protection, Biarritz, France, 9-13 May 2010. IRG Secretariat. IRG/WP 10-30542. https://www.irg-wp.com/irgdocs/details.php?3f18c1c7-832a-80ae-9309800a419dce94 
Ali, H.R.K.; Hashim, S.M. 2019. Determining Efficacy and Persistence of the Wood Preservative Copper Chrome Arsenate Type $\mathrm{C}$ against The Wood Destroying Insects and Treated Wood Durability. Egypt Acad J Biolog Sci 12(1): 65-78. https://dx.doi.org/10.21608/eajbsa.2019.26281

Ash, M.; Ash, I. 2004. Handbook of preservatives. Synapse Information Resources, Inc: New York, USA. 850. https://www.synapseinfo.com/pr03.htm

ASTM. 2005. Standard Test Method for Wood Preservatives by Laboratory Soil-Block Cultures. D141305. ASTM International: West Conshohocken, PA, USA. http://www.astm.org/cgi-bin/resolver.cgi?D1413

Bak, M.; Yimmou, B.M.; Csupor, K.; Ne'meth, R., Cso'ka, L. 2012. Enhancing the durabil- ity of wood against wood destroying fungi using nano-zink. In: International Scientific Conference on Sustainable Development \& Ecological Footprint, Budapest, Hungary, 16. http://cost-fp1006.fh-salzburg.ac.at/fileadmin/ documents/projects/Hungary/Enhancing_the_durability_of_wood_against_wood_destroying_fungi_using nano-zink.pdf

Borges, C.C.; Tonoli, G.H.D.; Cruz, T.M.; Duarte, P.J.; Junqueira, T.A. 2018. Nanoparticles-based wood preservatives: the next generation of wood protection. Cerne 24 (4): 397-407. https://doi.org/10.1590/0 1047760201824042531

Canadian Wood Council. 2020. Durability Solutions. http://cwc.ca/design-with-wood/ durability/durability-solutions/.

Cao, L.; Zhou, Z.; Niu, S.; Cao, C.; Li, X.; Shan, Y.; Huang, Q. 2018. Positive-Charge Functionalized Mesoporous Silica Nanoparticles as Nanocarriers for Controlled 2,4-Dichlorophenoxy Acetic Acid Sodium Salt Release. J Agric Food Chem 66(26): 6594-6603. https://doi.org/10.1021/acs.jafc.7b01957

Civardi, C.; Schwarze, F.W.; Wick, P. 2015. Micronized copper wood preservatives: an efficiency and potential health risk assessment for copper-based nanoparticles. Environ Pollut 200: 126-132. https://doi.org/10.1016/j.envpol.2015.02.018

Clausen, C.A. 2007. Nanotechnology: Implications for the wood preservation Industry. In $38^{\text {th }}$ the International Research Group on Wood Protection, Jackson Hole, WY, 20-24 May 2007. IRG Secretariat IRG/WP 07-30415. https://www.fpl.fs.fed.us/documnts/pdf2007/fpl_2007_clausen002.pdf

Clausen, C.A.; Green, F.; Kartal, S.N. 2010. Weatherability and leach resistance of wood impregnated with nano-zinc oxide. Nanoscale Res Lett 5: 1464-1467. https://doi.org/10.1007/s11671-010-9662-6

Creffield, J.W.; Greaves, H.; Howick, C.D. 1983. Boracol 40 - A potential remedial and preservative treatment for lyctids. In $14^{\text {th }}$ Annual Meeting of the International Research Group on Wood Protection, Surfers Paradise, Queensland, Australia, 9-13 May 1983. IRG Secretariat. IRG/WP 1192. https://www.irg-wp.com/ irgdocs/details.php?eeda9c60-0baa-42ae-a163-40472ba8234b

Creffield, J.W. 1996. Wood Destroying Insects-Wood Borers and Termites. 2nd Edn., CSIRO Division of Forestry and Forest Products. 44.www.earthlife.net/insects/pub/CSIRO.html

Dhillon, G.S.; Brar, S.K. Kaur, S.; Verma, M. 2012. Green approach for nanoparticle biosynthesis by fungi: current trends and applications. Crit Rev Biotechnol 32: 49-73. https://doi.org/10.3109/07388551.201 0.550568

Duhan, J.S.; Kumar, R.; Kumar, N.; Kaur, P.; Nehra, K.; Duhan, S. 2017. Nanotechnology: the new perspective in precision agriculture. Biotechnol Rep 15: 11-23. https://doi.org/10.1016/j.btre.2017.03.002

Dujardin, E.; Peet, C.; Stubbs, G.; Culver, J.N.; Mann, S. 2003. Organization of metallic nanoparticles using tobacco mosaic virus templates. Nano Lett 3: 413-417. https://doi.org/10.1021/n1034004o

Dwivedi, S.; Saquib, Q.; Ahmad, B.; Ansari, S.M.; Azam, A.; Musarrat, J. 2018. Toxicogenomics: a new paradigm for nanotoxicity evaluation. Adv Exp Med Biol 1048: 143-161. https://doi.org/10.1007/978-3319-72041-8 9 
Ezealisiji, K.M.; Siwe-Noundou, X.; Maduelosi, B.; Nwachukwu, N.W.; Krause, R.W.M. 2019. Green Synthesis of Zinc Oxide Nanoparticles Using Solanum torvum (L) leaf extract and evaluation of the Toxicological Profile of the ZnO Nanoparticles-Hydrogel Composite in Wistar Albino Rats. Inter Nano Lett 9: 99-107. https://doi.org/10.1080/17518253.2019.1687761

Fakhari, S.; Jamzad, M.; Kabiri Fard, H. 2019. Green synthesis of zinc oxide nanoparticles: a comparison. Green Chem Lett Rev 12(1): 19-24. https://doi.org/10.1080/17518253.2018.1547925

Fears, R.D.; Leca, J.L. 1995. Threshold levels for dip treatments of chlorpyrifos for borer control. In $26^{\text {th }}$ Annual Meeting of the International Research Group on Wood Protection, Helsingør, Denmark, 11-16 June 1995. IRG Secretariat. IRG/WP 95-10137. https://www.irg-wp.com/irgdocs/details.php?4b712422-fefd-4b7bb732-c91fa688a93c

Findlay, W.P.K. 1985. The nature and durability of wood. Findlay, W. P. K. (Ed.). In Preservation of timber in the tropics. https://doi.org/10.1007/978-94-017-2752-5

Freeman, M.H.; McIntyre, C.R. 2008. A comprehensive review of copper-based wood preservatives with a focus on new micronized or dispersed copper systems. J Forest Prod Res 58(11): 6-27. http://citeseerx. ist.psu.edu/viewdoc/download?doi=10.1.1.508.7748\&rep=rep1\&type=pdf

Gnanaharan, R.; Mathew, G.; Dhamodaran, T.K. 1983. Protection of rubber wood against the insect borer Sinoxylon anale Les. (Coleoptera : Bostrychidae). J Ind Acad Wood Sci 14(1): 9-11. https://pdfs.semanticscholar.org/c4c2/82a42e8ed5a0fe986ddff678bfbf636aa94b.pdf

Gnanaharan, R.; Mathew, G. 1982. Preservative treatment of rubber wood (Hevea brasiliensis). KFRI Research Report 15: 1-16. https://pdfs.semanticscholar.org/c4c2/82a42e8ed5a0fe986ddff678bfbf636aa94b. pdf

Gopinath, M.; Subbaiya, R.; Selvam, M.M.; Suresh, D.; Rangasamy, K. 2014. Synthesis of Copper Nanoparticles from Nerium oleander Leaf aqueous extract and its Antibacterial Activity. International Journal of Current Microbiology and Applied (9): 814-818. https://www.ijcmas.com/vol-3-9/M.Gopinath,\%20et\%20 al.pdf

Groenier, J.S.; Lebow, S. 2006. Preservative-treated wood and alternative products in the Forest Service. Tech. Rep. 0677-2809. USDA Forest Service. Technology and Development Program: Missoula, MT.

Gupta, H.; Sharma, K.R.; Sharma, J.N. 2017a. Fungal Inhibition in Wood Treated with Lantana camara L. Extract. In: Wood is Good: Current Trends and Future Prospects in Wood Utilization. Pandey, K; Ramakantha, V; Chauhan, S; Kumar, A. (eds) Springer: Singapore. 269-276. https://doi.org/10.1007/978-981$10-3115-125$

Gupta, H.; Sharma, K.R.; Chander Lekha.; Bhupender Dutt. 2017b. Potentials of Lantana camara L. leaf extract treatment for the dimensional stability of some lesser known wood species. J Pharmacogn Phytochem 6(4): 263-266. https://www.phytojournal.com/archives/?year=2017\&vol=6\&issue=4\&ArticleId=1353

Helal, H. 1983. Some biological informations about the small powder post beetle Lyctus africanus Leone. in Egypt (Coleoptera, Lyctidae). Agricultural research review 59 (1): 167-175.

Hulkoti, N.I.; Taranathm, T.C. 2014. Biosynthesis of nanoparticles using microbes-a review. Colloids and Surfaces B: Biointerfaces 121: 474-483. https://doi.org/10.1016/j.colsurfb.2014.05.027

Humar, M.; Petrič, M.; Pohleven, F. 2001. Leaching of copper from wood treated with copper-based wood preservatives. Drvna industrija 52: 111-116.

Husen, A.; Iqbal, M. 2019. Nanomaterials and plant potential: an overview. In: Nanomaterials and Plant Potential. Husen, A.; Iqbal, M. (Eds). Springer Cham. https://doi.org/10.1007/978-3-030-05569-1_1

Iravani, S. 2011. Green synthesis of metal nanoparticles using plants. Green Chem 13: 2638-2650. https://doi.org/10.1039/C1GC15386B 
IS. 2008. Methods of laboratory testing of wood preservatives against fungi and borers powder post beetles, Second Revision. Part-2, Determination of threshold values of wood preservatives against borers (powder post beetles). IS 4873-2008. 1-5. Bureau of Indian Standards: New Delhi. https://standardsbis.bsbedge.com/ BIS_searchstandard.aspx?Standard_Number $=$ IS $+4873+\% 3 \mathrm{a}+$ Part $+2 \& \mathrm{id}=33785$

Ito, T. 1983. Tasting behavior of Lyctus brunneus Stephens (Coleoptera: Lyctidae). Appl Ent Zool 18 (2): 289-292. https://doi.org/10.1303/aez.18.289

Kalawate, A. 2013. Evaluation of Copper Ethanolamine Boron Based Wood Preservative to Control Wood Destroying Insects. Mol Entomol 4 (2): 6-12. http://www.ecoevopublisher.com/index.php/me/article/ view/632/727

Kartal, S.N.; Green, F.; Clausen, C.A. 2009. Do the unique properties of nanometals affect leachability or efficacy against fungi and termites? International Biodeterioration \& Biodegradation 63: 490-495. https:// doi.org/10.1016/j.ibiod.2009.01.007

Kartika, T.; Yoshimura, T. 2013. Nutritional quality of diet and fecundity in Lyctus africanus (Lesne). Procedia Environ Sci 17: 97-104. https://doi.org/10.1016/j.proenv.2013.02.016

Khan, S.A.; Shahid, S.; Sajid, M.R.; Noreen, F.; Kanwal, S. 2017. Biogenic Synthesis of CuO Nanoparticles and their Biomedical Applications: A Current Review. International Journal of Advanced Research 5(6):925-946. http://dx.doi.org/10.21474/IJAR01/4495

Khot, L.R.; Sankaran, S.; Maja, J.M.; Ehsani, R.; Schuster, E.W. 2012. Applications of nanomaterials in agricultural production and crop protection: a review. Crop Protection 35:64-70. https://doi.org/10.1016/j.cropro.2012.01.007

Kumar, S.; Kumar, D.; Dilbaghi, N. 2017. Preparation, characterization, and bio-efficacy evaluation of controlled release carbendazim-loaded polymeric nanoparticles. Env Sci Pollut Res 24: 926-937. https://doi.org/10.1007/s11356-016-7774-y

Lebow, S.T. 1996. Leaching of wood preservative components and their mobility in the environment-Summary of pertinent literature. Gen. Tech. Rep. FPL-GTR-93, United States Department of Agriculture, Forest Service, Forest Products Laboratory, Madison: WI. 36. https://doi.org/10.2737/FPL-GTR-93

Lebow, S.T. 2010. Wood Preservation. In Wood Handbook: Wood as an Engineering Material. United States Department of Agriculture, Forest Service, Forest Products Laboratory Madison: WI. 328-355. https://www.fpl.fs.fed.us/documnts/fplgtr/fpl_gtr190.pdf

Lee, H.J.; Lee, G.; Jang, N.R.; Yun, J.H.; Song. J.Y.; Kim, B.S. 2011. Biological synthesis of copper nanoparticles using plant extract. Nanotechnology 1(1): 371-374. https://briefs.techconnect.org/wp-content/ volumes/Nanotech2011v1/pdf/146.pdf

Lepage, E.; Salis, A.G. de.; Guedes, E.C.R. 2017. Tecnologia de proteção da madeira. Montana Quimica: São Paulo, SP. Brazil.

Lykidis, C.; Teresa De T.; Conde, M.; Galvan, J.; Mantanis, G. 2016. Termite resistance of beech wood treated with zinc oxide and zinc borate nanocompounds. Wood Material Science \& Engineering 13(1): 45-49. https://doi.org/10.1080/17480272.2016.1257651

Majumder, D.R. 2012. Bioremediation: Copper Nanoparticles from Electronic-waste. International Journal of Engineering, Science and Technology 4(10): 4388-4389. https://www.ajol.info/index.php/ijest/issue/ archive

Mandava, K.; Kadimcharla, K.; Keesara, N.R.; Sumayya, N.F.; Prathyusha, B.; Batchu, U.R. 2017. Green synthesis of stable copper nanoparticles and synergistic activity with antibiotics. Indian Journal of Pharmaceutical Sciences 79 (5): 695-700. https://doi.org/10.4172/pharmaceutical-sciences.1000281

Mantanis, G.; Terzi, E.; Kartal, S.N.; Papadouplos, A.N. 2014. Evaluation of mold, decay and termite resistance of pine wood treated with zinc and copper based nanocompounds. International Biodeterioration \& Biodegradation 90: 140-144. https://doi.org/10.1016/j.ibiod.2014.02.010 
Mittal, A.K.; Chisti, Y.; Banerjee, U.C. 2013. Synthesis of metallic nanoparticles using plant extracts. Biotechnology Advances 31: 346-356. https://doi.org/10.1016/j.biotechadv.2013.01.003

Moghaddam, A.B.; Namvar, F.; Moniri, M.; Tahir, S.; Azizi, P.M.; Mohamad, R. 2015. Nanoparticles biosynthesized by fungi and yeast: a review of their preparation, properties, and medical applications. Molecules 20: 16540-16565. https://doi.org/10.3390/molecules200916540

Nair, K.S.S.; Mathew, G. 1984. Dried tapioca tuber for laboratory rearing of the bamboo borer, Dinoderus minutus Fabr. (Coleoptera:Bostrychidae). Material Und Organismen 19(1): 49-54. https://www.inbar.int/resources/article/dried-tapioca-tuber-for-laboratory-rearing-of-the-bamboo-borer-dinoderus-minutus-fabr-coleoptera-bostrychidae/

Nair, S.; Pandey, K.K.; Giridhar, B.N.; Vijayalakshmi, G. 2017. Decay resistance of rubberwood (Hevea brasiliensis) impregnated with $\mathrm{ZnO}$ and $\mathrm{CuO}$ nanoparticles dispersed in propylene glycol. International Biodeterioration \& Biodegradation 122: 100-106. https://doi.org/10.1016/j.ibiod.2017.05.008

Nair, S.; Giridhar, B.N.; Pandey, K.K. 2018. UV stabilization of wood by nano metal oxides dispersed in propylene glycol. J Photoch Photobio B 183:1-10. https://doi.org/10.1016/j.jphotobiol.2018.04.007

Oliveira, H.C.; Stolf-Moreira, R.; Martinez, C.B.R.; Grillo, R.; de Jesus, M.B.; Fraceto, L.F. 2015. Nanoencapsulation enhances the post-emergence herbicidal activity of Atrazine against mustard plants. PLOS One 10(7): e0132971. https://doi.org/10.1371/journal.pone.0132971

Peters, B.C.; Creffield, J.W.; Edridge, R.H. 2002. Lyctine (Coleoptera Bostrichidae) pests of timber in Australia: A literature review and susceptibility testing protocol. Aust For 65 (2): 107-119. https://doi.org/10.1080/00049158.2002.10674861

Platten, W.; Luxton, T.; Gerke, T.; Harmon, S.; Sylvest, N.; Bradham, K.; Rogers, K. 2014. Release of Micronized Copper Particles from Pressure Treated Wood Products. U.S. Environmental Protection Agency: Washington, DC, EPA/600/R-14/365. http://nepis.epa.gov/Adobe/PDF/P100LJWI.pdf

Punjabi, K.; Choudhary, P.; Samant, L.; Mukherjee, S.; Vaidya, S.; Chowdhary, A. 2015. Biosynthesis of nanoparticles: a review. International Journal of Pharmaceutical Sciences Review and Research 30: 219-226.

Raffi, M.M.; Husen, A. 2019. Impact of fabricated nanoparticles on the rhizospheric microorganisms and soil environment. In Nanomaterials and Plant Potential. Husen, A.; Iqbal, M. (Eds.). Springer International Publishing AG, Cham. 529-552. https://doi.org/10.1007/978-3-030-05569-1_21

Remadevi, O.K.; Muthukrishnan, R. 1997. Efficacy of chlorpyriphos as protectant of wood against borer and termite attack. Wood News 7(1): 22-25. https://www.cabdirect.org/cabdirect/abstract/19970611219?start $=1500$

Richardson, H.W. 1997. Handbook of Copper Compounds and Applications. CRC Press. https://doi.org/10.1201/9781482277463

Schrofel, A.; Kratosova, G.; Krautova, M.; Dobrocka, E.; Vavra, I. 2011. Biosynthesis of gold nanoparticles using diatoms-silica gold and EPS-gold bionanocomposite formation. Journal of Nanoparticle Research 13: 3207-3216. https://doi.org/10.1007/s11051-011-0221-6

Sekhon, B.S. 2014. Nanotechnology in agri-food production: an overview. Nanotechnol Sci Appl 7: 31-53. https://doi.org/10.2147/NSA.S39406

Shiny, K.S.; Sundararaj, R.; Mamatha, N.; Lingappa, B. 2019. A new approach to wood protection: preliminary study of biologically synthesized copper oxide nanoparticle formulation as an environmental friendly wood protectant against decay fungi and termites. Maderas-Cienc Tecnol 21(3): 347- 356. http://dx.doi.org/10.4067/S0718-221X2019005000307.

Siddiqui, M.A.; Alhadlaq, H.A.; Ahmad, J.; Al-Khedhairy, A.A.; Musarrat, J.; Ahamed, M. 2013. Copper oxide nanoparticles induced mitochondria mediated apoptosis in human hepatocarcinoma cells. PLOS One 8(8): e69534. https://doi.org/10.1371/journal.pone.0069537 
Singh, J.; Dutta, T.; Kim, K.H.; Rawat, M.; Samddar, P.; Kumar, P. 2018. 'Green' synthesis of metals and their oxide nanoparticles: applications for environmental remediation. $J$ Nanobiotechnol 16(84): 1-24. https://doi.org/10.1186/s12951-018-0408-4

Singaravelu, G.; Arockiamary, J.S.; Ganesh Kumar, V.; Govindaraju, K. 2007. A novel extracellular synthesis of monodisperse gold nanoparticles using marine alga, Sargassum wightii Greville. Colloids and Surfaces B: Biointerfaces 57: 97-101. https://doi.org/10.1016/j.colsurfb.2007.01.010

Tan, C.K.S.; Hong, L.T.; Wong, Andrew.; Chang, J.J.M.; Tsang, A; Leong, P.T.; Tang, C.S.; Tan, C.C.L.; Loh, E.K.S.; Ng, W.P. 2003. Understanding timber preservation - a guide to timber and its treatment to enhance wood durability. Malaysian Wood Preserving Association. 41.

Tascioglu, C.; Mesut, Y.; Selim, S.; Caglar, A. 2013. Antifungal properties of some plant extracts used as wood preservatives. International Biodeterioration \& Biodegradation 85(1): 23-28. https://doi.org/10.1016/j. ibiod.2013.06.004

Temiz, A.; Alfredsenl, G.; Yildiz, U.C.; Engin, D.G.; Kose, G.; Akbas, S.; Yildiz, S. 2014. Leaching and decay resistance of alder and pine wood treated with copper based wood preservatives. Maderas-Cienc Tecnol 16(1): 63-76. https://scielo.conicyt.cl/scielo.php?script=sci_arttext\&pid=S0718-221X2014000100006

Terzi, E.; Kartal, S.N.; Yılgör, N.; Rautkari, L.; Yoshimura, T. 2016. Role of various nano-particles in prevention of fungal decay, mold growth and termite attack in wood, and their effect on weathering properties and water repellency. International Biodeterioration \& Biodegradation 107:77-87. https://doi.org/10.1016/j. ibiod.2015.11.010

Tolley, M.P.; Laks, P.E.; Fears, R. 1998. Evaluation of chlorpyrifos and fungicides alone and in combination for control of insects and fungi in wood and wood composites. In $29^{\text {th }}$ Annual Meeting of the International Research Group on Wood Protection, Maastricht, Netherlands, 14-19 June 1998. IRG Secretariat. IRG/ WP 98-30187. https://www.irg-wp.com/irgdocs/details.php?6ad45c82-e3c8-4e51-9adf-3b7bac8c35c1

Van Acker, J.; Stevens, M.; Pallaske, M. 1990. Insect resistance of preservative treated tropical plywood against Lyctus. In 21st Annual Meeting of the International Research Group on Wood Protection, Rotorua, New Zealand, 13-19 May 1990. IRG Secretariat. IRG/WP/1453. https://www.irg-wp.com/irgdocs/details. php?07ce4347-6d50-4181-86ed-06858602e9b3

Venmalar, D. 2017. Screening of Oils of Pongamia pinnata Linn, Jatropha curcas Linn and Simarouba glauca D.C. for developing Eco-Friendly Wood Preservatives. In: Wood is Good: Current Trends and Future Prospects in Wood Utilization. Pandey, K; Ramakantha, V; Chauhan, S; Kumar, A. (eds) Springer: Singapore. 261-268. https://doi.org/10.1007/978-981-10-3115-1_24

Vijayaraghavan, K.; Ashokkumar, T. 2017. Plant-mediated biosynthesis of metallic nanoparticles: A review of literature, factors affecting synthesis, characterization techniques and applications. $J$ Environ Chem Eng 5: 4866-4883. http://dx.doi.org/10.1016/j.jece.2017.09.026

Wagay, J.A.; Singh, S.; Raffi, M.M.; Rahman, Q.I.; Husen, A. 2019. Impact of carbon- based nanomaterials on plant functioning and rhizosphere. In: Nanomaterials and Plant Potential. Husen, A.; Iqbal, M. (Eds.). Springer International Publishing AG. Cham.553-575. https://doi.org/10.1007/978-3-030-05569-1_22

Zabel, R.A.; Morrell, J.J. 1992. Wood Microbiology: Decay and Its Prevention. Academic Press: London. https://www.elsevier.com/books/wood-microbiology/zabel/978-0-12-775210-5

Zandi-Sohani, N.; Hojjati, M.; Carbonell-Barrachina, A.A. 2012. Bioactivity of Lantana camara L. essential oil against Callosobruchus maculatus (Fabricius). Chilean J Agric Res 72(4): 502-506. http://dx.doi. org/10.4067/S0718-58392012000400007. 